\title{
PENGARUH PENDEKATAN PEMBELAJARAN KONTEKSTUAL DAN KEMAMPUAN NUMERIK TERHADAP PRESTASI BELAJAR MATEMATIKA SISWA KELAS VIII SMP NEGERI 3 ABANG
}

\author{
Ida Ayu Nyoman Sri Wijayanthi, I Wayan Santyasa, Ketut Agustini \\ Program Studi Teknologi Pembelajaran, Program Pascasarjana \\ Universitas Pendidikan Ganesha \\ Singaraja, Indonesia
}

e-mail: \{sri.wijayanthi, wayan.santyasa, ketut.agustini\}@pasca.undiksha.ac.id

\begin{abstract}
Abstrak
Penelitian ini bertujuan mendeskripsikan pengaruh pembelajaran kontekstual dan kemampuan numerik terhadap prestasi belajar matematika. Penelitian eksperimen semu ini menggunakan rancangan non-equivalent pretest-posttest control group design. Populasinya adalah 5 kelas siswa kelas VIII SMP Negeri 3 Abang Tahun Pelajaran 2016/2017. Sampel sebanyak 4 kelas diambil secara random, kemudian dirandom kembali untuk menentukan 2 kelas sebagai kelompok eksperiman dengan perlakuan pembelajaran kontekstual dan 2 kelas yang lain sebagai kelompok kontrol dengan perlakuakan pembelajaran konvensional. Data kemampuan numerik dan prestasi belajar matematika dikumpulkan dengan tes. Data penelitian dianalisis dengan uji statistik Anacova Dua Jalan. Setelah perlakuan dikontrol dengan kovariabel prestasi belajar matematika awal, hasil penelitian menunjukkan hal-hal sebagai berikut. (1) Terdapat perbedaan secara signifikan prestasi belajar matematika antara siswa yang belajar dengan pembelajaran kontekstual dan siswa yang belajar dengan pembelajaran konvensional. Nilai prestasi belajar matematika siswa yang belajar dengan pembelajaran kontekstual lebih tinggi dibandingkan dengan siswa yang belajar dengan pembelajaran konvensional. (2) Terdapat perbedaan prestasi belajar matematika antara siswa yang memiliki kemampuan numerik tinggi dan siswa yang memiliki kemampuan numerik rendah. Nilai prestasi belajar matematika siswa yang memiliki kemampuan numerik tinggi lebih tinggi dibandingkan siswa yang memiliki kemampuan numerik rendah. (3) Terdapat pengaruh interaktif antara pendekatan pembelajaran dan kemampuan numerik terhadap terhadap prestasi belajar matematika.
\end{abstract}

Kata kunci: pendekatan pembelajaran kontekstual, kemampuan numerik, prestasi belajar matematika

\begin{abstract}
This research aimed at describing the effect of contextual teaching learning (CTL) and numerical ability (NA) upon students' achievment on mathematics. This quasi-experimental research used nonequivalent pretest-posttest control group designed. The population in this study were five clases of the eighth grade students of SMP Negeri 3 Abang in the academic year of 2016/2017. The selection of the samples for this study were based on random technique, four clases were selected as the samples, two clases as the experimental group with the CTL treatment and the others are the control group with conventional learning. The data of numerical ability and students' achievment on mathematics were collected by test. The data obtained then were analyzed by using two ways Ancova. After treatment was controlled by pre-students'achievment on mathematics as a covariable,the results of this study were as followes. (1) There was a significant difference of students' achievment bertween contextual CTL and conventional groups. Students who learned with CTL approach got higher achievment than them learned with conventional approach. (2) There was a significant difference of the students' achievment between them with high numerical ability and them with low numerical ability. The students'achievment on mathematics of students who had high numerical ability was higher than them who had low numerical ability. (3) There was an interaction effect between learning approach (CTL approach and conventional approach) and numerical ability (high and low numerical ability) upon students' achievement on mathematics.
\end{abstract}

Keywords: contextual teaching learning approach, numerical ability, students' achievment on mathematics. 


\section{PENDAHULUAN}

Pendidikan merupakan satu komponen yang sangat signifikan untuk menunjang keberhasilan pembangunan bangsa. Berkaitan dengan tuntutan untuk menghasilkan sumber daya manusia yang berkualitas, dunia pendidikan memiliki peranan yang sangat penting. Tujuan pendidikan nasional yang dirumuskan dalam Undang-Undang Nomor 20 Tahun 2003 adalah untuk berkembangnya potensi siswa agar menjadi manusia yang beriman dan bertaqwa kepada Tuhan Yang Maha Esa, berakhlak mulia, sehat, berilmu, cakap, kreatif, mandiri dan menjadi warga negara yang demokratis serta bertanggung jawab (Budimah, 2014). Sesuai dengan bunyi undang-undang tersebut masalah pendidikan menjadi tanggung jawab semua pihak. Lembagalembaga pendidikan harus mampu mewujudkan perannya secara efektif dan efisien untuk mewujudkan tujuan tersebut.

Upaya yang dilakukan pemerintah untuk menghasilkan sumber daya manusia yang berkualitas dan profesional adalah meningkatkan kualitas pendidikan, yaitu dengan melakukan penyempurnaan sistemik terhadap seluruh komponen pendidikan Dengan adanya berbagai usaha pemerintah ini, seyogyanya mutu pendidikan nasional menjadi lebih baik. Pendidikan yang merupakan salah satu fungsi terpenting dalam membantu perkembangan pribadi, kelompok, masyarakat, kebudayaan nasional bangsa dan Negara. Melalui pendidikan kita berharap semua bakat, kemampuan dan kemungkinan yang dimiliki bisa dikembangkan secara maksimal agar kita bisa mandiri dalam proses pembangunan pribadi sebagai manusia.

Pendidikan tidak hanya dipandang sebagai usaha pemberian informasi dan pembentukan ketrampilan, tetapi diperluas sehingga mencakup usaha untuk mewujudkan keinginan, kebutuhan, dan kemampuan individu sehingga tercapai pola hidup pribadi dan sosial yang memuaskan, pendidikan bukan sematamata sebagai sarana untuk persiapan kehidupan yang akan datang, melainkan untuk kehidupan anak sekarang yang sedang mengalami perkembangan menuju ke tingkat kedewasaan.

Prinsip tersebut menyebabkan adanya pergeseran paradigma proses pendidikan, dari paradigma pengajaran ke paradigma pembelajaran. Paradigma pengajaran yang lebih menitikberatkan peran pendidik dalam mentransformasikan pengetahuan kepada siswanya bergeser pada paradigma pembelajaran yang memberikan peran lebih banyak kepada siswa untuk mengembangkan potensi dan kreativitas dirinya dalam rangka membentuk manusia yang memiliki kekuatan spiritual keagamaan, berakhlak mulia, berkepribadian, memiliki kecerdasan, memiliki estetika, sehat jasmani dan rohani, serta ketrampilan yang dibutuhkan bagi dirinya, masyarakat, bangsa dan negara. Dalam pergeseran paradigma pendidikan dari paradigma pengajaran ke paradigma pembelajaran, teknologi pembelajaran tentunya memiliki peran yang sangat penting.

Teknologi pembelajaran adalah teori dan praktik dalam perancangan, pengembangan, pemanfaatan, pengelolaan, serta evaluasi proses dan sumber belajar (Seels \& Richey, 1994). Definisi ini dirumuskan berdasarkan lima bidang garapan bagi teknolog pembelajaran, yaitu perancangan, pengembangan, pemanfaatan, pengelolaan, dan evaluasi. Kelima hal ini merupakan kawasan bidang teknologi pembelajaran. Masing-masing kawasan dalam bidang teknologi pembelajaran terdiri dari beberapa komponen. Kelima kawasan teknologi pembelajaran merupakan bidang garapan teknologi pembelajaran yang saling berhubungan satu dengan yang lainnya.

Teknologi pembelajaran berupaya untuk merancang, mengembangkan, memanfaatkan, mengelola dan mengevaluasi aneka sumber belajar sehingga dapat memudahkan dan memfasilitasi seseorang untuk belajar. Dengan demikian teknologi pembelajaran berperan dalam upaya pemecahan masalah pendidikan dan pembelajaran 
dengan cara: 1) memadukan berbagai macam pendekatan dari bidang ekonomi, manajemen, psikologi, rekayasa dan lainlain secara bersistem; 2) memecahkan masalah belajar pada manusia secara menyeluruh dan serempak, dengan memperhatikan dan mengkaji semua kondisi dan saling kaitan di antaranya; 3) menggunakan teknologi sebagai proses dan produk untuk membantu memecahkan masalah belajar; 4) timbulnya daya lipat atau efek sinergi, dimana penggabungan pendekatan dan atau unsur-unsur mempunyai nilai lebih dari sekedar penjumlahan (Miarso, 2004). Dengan pula pemecahan secara menyeluruh dan serempak akan mempunyai nilai lebih daripada memecahkan masalah secara terpisah.

dalam Peranan teknologi pendidikan
pembelajaran khususnya perluasan akses dan peningkatan mutu pendidikan, melalui: 1) penerapan prosedur pengembangan pembelajaran dalam penyusunan Kurikulum Tingkat Satuan Pendidikan (KTSP), struktur dan muatan kurikulum, kalender pendidikan, silabus dan perangkat pembelajaran lain seperti Rencana Pelaksanaan Pembelajaran (RPP); 2) penerapan prosedur pengembangan pembelajaran dalam penyusunan bahan ajar, modul, buku teks, atau buku elektronik; 3) penerapan pendekatan pembelajaran yang lebih menekankan pada penerapan teori-teori belajar mutakhir seperti teori belajar konstruktivisme dan paradigma baru pendidikan yag lain; 4) mengembangkan dan memanfaatkan berbagai jenis media yang sesuai dengan kebutuhan dan dengan mengindahkan prinsip-prnsip pemanfaatannya secara efektif dan efisien, dan mengembangkan; 5) mengembangkan strategi pembelajaran untuk membangun dan menemukan jati diri melalui proses pembelajaran yang aktif, interaktif, kreatif, efektif dan menyenangkan; dan 6) melakukan evaluasi untuk menganalisis permasalahan dan mengetahui memadai atau tidaknya proses pembelajaran.
Dalam kaitannya dengan proses pembelajaran, salah satu ilmu yang mempunyai peran penting dalam berbagai disiplin ilmu dan mengembangkan daya pikir manusia adalah Matematika. Matematika merupakan ilmu dasar (basic sciences) sebagai logika berpikir. Matematika telah banyak mengajarkan manusia mengenal dan menjelaskan fenomena-fenomena yang terjadi di sekelilingnya.

Menurut Permendiknas No. 22 Tahun 2006, mata pelajaran matematika bertujuan agar peserta didik memiliki kemampuan sebagai berikut.1) Memahami konsep matematika, menjelaskan keterkaitan antar konsep dan mengaplikasikan konsep atau algoritma, luwes, akurat, efisien, dan tepat, dalam pemecahan masalah, 2) Menggunakan penalaran pada pola dan sifat, melakukan manipulasi matematika dalam membuat generalisasi, menyusun bukti, atau menjelaskan gagasan dan pernyataan matematika, 3) Memecahkan masalah yang meliputi kemampuan memahami masalah, merancang model matematika, menyelesaikan model dan menafsirkan solusi yang diperoleh, 4) Mengkomunikasikan gagasan dengan simbol, tabel, diagram, atau media lain untuk memperjelas keadaan atau masalah, 4) Menghargai kegunaan matematika dalam kehidupan, yaitu memiliki rasa, ingin tahu, perhatian, dan minat dalam mempelajari matematika, serta sikap ulet dan percaya diri dalam pemecahan masalah, 5) Penalaran secara logis dan kritis serta mengembangkan aktifitas kreatif dalam memecahkan masalah dan mengkomunikasikan ide.

$$
\text { Begitu pentingnya peranan }
$$

matematika, seharusnya siswa mempelajarinya dengan baik dan menyenangkan. Pada kenyataannya, proses pembelajaran yang ada selama ini belum optimal, karena siswa masih belum aktif dalam mengikuti pembelajaran. Pembelajaran yang dilaksanakan masih monoton dan kurang inovatif dalam memilih pendekatan pembelajaran yang tepat dan efektif. Pembelajaran yang cenderung dilaksanakan adalah 
pendekatan pembelajaran konvensional yang merupakan proses pembelajaran yang cenderung berpusat pada guru (teacher centered). Guru juga kurang mampu menghubungkan pengetahuan formal dengan pengalaman siswa seharihari sehingga banyak siswa berpendapat bahwa pelajaran matematika hanya dipelajari di sekolah saja tanpa ada hubungannya dengan kehidupan seharihari.

Hal tersebut menyebabkan matematika menakutkan atau mata pelajaran yang tidak disukai siswa, sehingga hasil ulangan sumatif, atau ulangan harian tidak begitu memuaskan, banyak yang remidial (tidak tuntas). Berdasarkan data awal dari kelas VIII SMP Negeri 3 Abang, bahwa prestasi belajar matematika pada waktu di kelas VIII semester Ganjil dapat dikatakan rendah. Hal ini dapat dilihat dari hasil ulangan akhir semester ganjil kelas VIII yang rata-ratanya di bawah KKM mata pelajaran matematika yang dipersyaratkan sekolah yaitu 70,00 .

Penyebab kesulitan siswa dalam mempelajari matematika adalah berasal dari beberapa karakteristik matematika itu sendiri, antara lain: 1) memiliki objek kajian yang abstrak, 2) bertumpu pada kesepakatan, 3) berpola pikir deduktif, 4) memiliki simbol yang kosong dari arti, 5) memperhatikan semesta pembicaraan, dan 6) konsisten dalam sistemnya, Soedjadi (dalam Wiswayana, 2007). Karakteristik matematika tersebut, tidak hanya menyebabkan matematika sulit dipelajari siswa, tetapi juga sulit diajarkan oleh guru matematika itu sendiri.

$$
\text { Jenning dan Dunne (dalam }
$$

Kawiwati, 2009) mengatakan bahwa kebanyakan siswa mengalami kesulitan dalam mengaplikasikan matematika ke dalam situasi kehidupan nyata. Hal ini disebabkan karena guru dalam pembelajaran di kelas kurang memberikan kesempatan kepada siswa untuk menemukan dan mengkonstruksi sendiri ide matematika yang dimilikinya. Menghubungkan pengalaman kehidupan nyata anak dengan ide-ide matematika dalam pembelajaran di kelas penting dilakukan agar pembelajaran lebih bermakna. Hal ini dipertegas oleh HeuvelPanhuizen (dalam Kawiwati, 2009) yang mengatakan bahwa bila anak belajar matematika terpisah dari pengalaman sehari-hari maka anak akan cepat lupa dan tidak dapat mengaplikasikan matematika. Jadi pembelajaran matematika di kelas ditekankan pada keterkaitan antara konsep-konsep matematika dengan pengalaman anak sehari-hari.

Untuk mengatasi permasalahan tersebut, ada beberapa upaya yang akan dilaksanakan agar pembelajaran berjalan dengan produktif dan bermakna bagi siswa, salah satunya adalah penggunaan pendekatan pembelajaran kontekstual. Pendekatan kontekstual merupakan sebuah pendekatan pembelajaran dengan multi strategi yang "membawa" siswa belajar ke dalam konteksnya. Siswa akan lebih terdorong dan mampu menghubungkan pengetahuan yang dimilikinya dengan penerapannya dalam konteks kehidupan mereka sehari-hari. Proses pembelajaran kontekstual dapat memfasilitasi siswa secara aktif bekerja dan mengalami, sehingga siswa tidak lagi menjadi pengamat pasif tetapi menjadi aktif dan bertanggung jawab terhadap belajarnya.

Depdiknas (2002) dan Johnson (2002) menyatakan bahwa konsep dan definisi pendekatan pembelajaran kontekstual memiliki landasan psikologi kognitif, psikologi sosial, dan teori belajar konstruktivistik. Pembelajaran kontekstual merupakan sebuah pendekatan pembelajaran dengan multi strategi yang "membawa" siswa belajar ke dalam konteksnya. Siswa akan lebih terdorong dan mampu menghubungkan pengetahuan yang dimilikinya dengan penerapannya dalam konteks kehidupan mereka sehari-hari (sebagai anggota keluarga dan masyarakat). Guru lebih banyak berperan sebagai fasilitator bagi siswa untuk mencapai tujuan belajar. Dengan kata lain bahwa aktivitas guru di kelas banyak berurusan dengan strategi daripada memberi informasi. Tugas guru mengelola kelas sebagai sebuah tim yang 
bekerja sama untuk menemukan "pengetahuan dan keterampilan" yang baru bagi siswa (dengan cara menemukan sendiri, bukan dari apa kata guru).

$\begin{array}{lll}\text { Menurut Santyasa } & \text { (2012) }\end{array}$

pendekatan kontekstual dalam pembelajaran merupakan suatu konsepsi yang membantu siswa mengaitkan konten mata pelajaran dengan situasi dunia nyata dan memotivasi siswa membuat hubungan antara pengetahuan dan penerapannya dalam kehidupan sehari-hari. Pendekatan kontekstual memungkinkan siswa untuk menguatkan, memperluas dan menerapkan pengetahuan dan keterampilan akademik mereka dalam kehidupan mereka baik disekolah maupun di luar sekolah.

Sedangkan pada pendekatan pembelajaran konvensional guru lebih sering menggunakan strategi atau metode ceramah dan/atau drill dengan mengikuti urutan materi dalam kurikulum secara ketat. Guru berasumsi bahwa keberhasilan program pembelajaran dilihat dari ketuntasannya menyampaikan seluruh materi yag ada dalam kurikulum. Penekanan aktivitas belajar lebih banyak pada buku teks dan kemampuan mengungkapkan kembali isi buku teks tersebut.

Hal lain yang perlu mendapat perhatian dalam meningkatkan pencapaian prestasi belajar matematika adalah kemampuan numerik sebagai kemampuan dasar yang dimiliki siswa dalam memahami mata pelajaran matematika. Kemampuan numerik merupakan kemampuan dasar dalam belajar matematika khususnya yang berhubungan dengan operasi bilangan seperti menjumlahkan, mengurangi, mengalikan, membagi, perpangkatan, dan penarikan akar. Di samping itu yang tercakup dalam kemampuan numerik adalah kemampuan mengaplikasikan dalam hitung-menghitung, kecekatan, ketepatan, dan ketelitian.

Berdasarkan uraian di atas, penelitian ini mencoba untuk mendeskripsikan pengaruh pendekatan pembelajaran kontekstual dan kemampuan numerik terhadap prestasi belajar matematika siswa kelas VIII SMP Negeri 3 Abang.

Penelitian ini bertujuan: (1) untuk mendeskripsikan perbedaan prestasi belajar matematika antara siswa yang mengikuti pendekatan pembelajaran kontekstual dan siswa yang mengikuti pendekatan pembelajaran konvensional setelah perlakuan dikontrol dengan kovariabel prestasi belajar matematika awal, (2) untuk mendeskripsikan perbedaan prestasi belajar matematika antara siswa yang memiliki kemampuan numerik tinggi dan siswa yang memiliki kemampuan numerik rendah setelah perlakuan dikontrol dengan kovariabel prestasi belajar matematika awal, dan (3) untuk mendeskripsikan pengaruh interaktif antara pendekatan pembelajaran dengan kemampuan numerik siswa dalam pencapaian prestasi belajar matematika siswa setelah perlakuan dikontrol dengan kovariabel prestasi belajar matematika awal.

\section{METODE}

Penelitian kuasi eksperimen ini menggunakan non-equivalent pretestposttest control group design. Rancangan analisis data yang digunakan dalam penelitian ini adalah ANACOVA dua jalan dengan faktor pemilah adalah variabel moderator kemampuan numerik tinggi dan kemampuan numerik rendah. Populasi penelitian ini adalah 5 kelas siswa kelas VIII SMP Negeri 3 Abang dengan jumlah siswa sebanyak 176 orang. Sampel sebanyak 4 kelas ditentukan secara random, yang kemudian dirandom kembali untuk menetapkan 2 kelas menggunakan pendekatan pembelajaran kontekstual yaitu kelas VIII B dan VIII C dan 2 kelas lain sebagai kelas kontrol menggunakan pendekatan pembelajaran konvensional yaitu kelas VIIIA dan Kelas VIII E.

Penelitian ini menggunakan metode pengumpulan data dengan teknik tes. Data yang diperlukan dalam penelitian ini adalah data tentang kemampuan numerik, prestasi belajar Matematika awal dan prestasi belajar Matematika siswa. 
Data tentang kemampuan numerik dikumpulkan dengan tes kemampuan numeri yang sudah diujicobakan sebelumnya dan diberikan sebelum perlakuan, data tentang prestasi belajar Matematika awal siswa dikumpulkan dengan tes prestasi belajar matematika yang telah diujicobakan terlebih dahulu dan diberikan sebelum perlakuan dan tes prestasi belajar matematika dikumpulkan dengan tes prestasi belajar matematika yang sudah diujicobakan sebelumnya dan diberikan setelah perlakuan. Bentuk tes kemampuan numerik dan tes prestasi belajar matematika siswa adalah pilihan ganda yang terdiri dari 30 butir soal. Pemberian skor untuk setiap butir soal bagi siswa yang menjawab benar adalah satu, dan untuk setiap siswa yang menjawab salah atau tidak menjawab adalah nol.

Teknik analisis yang dipergunakan dalam penelitian ini adalah analisis deskriptif dan analisis kovarian. Analisis deskriptif digunakan untuk menganalisis data mean, median, modus, standar deviasi dan varian. Untuk melakukan uji hipotesis menggunakan ANACOVA dua jalan. Asumsi analisis kovarian, bahwa data berdistribusi normal (uji normalitas), varian homogen (uji homogenitas varian) dan linieritas antara kovariat dan variabel terikat (uji linearitas) sudah terpenuhi. Data tersebut akan dianalisis menggunakan SPSS 16.0 for windows dengan pengujian hipotesis pada taraf signifikansi $5 \%$.

\section{HASIL DAN PEMBAHASAN}

Deskripsi

umum

yang

dipaparkan sebagi hasil dari penelitian ini adalah deskripsi skor rata-rata, dan standar deviasi prestasi belajar matematika yang diperoleh dari hasil pretes dan postes berdasarkan pendekatan pembelajaran kontekstual dan pendekatan pembelajaran konvensional. Objek dalam penelitian ini adalah perbedaan prestasi belajar matematika sebagai hasil perlakuan antara penerapan pendekatan pembelajaran kontekstual dan pendekatan pembelajaran konvensional dengan mempertimbangkan kemampuan numerik siswa. Rekapitulasi hasil perhitungan deskriptif dijabarkan dalam Tabel 1

Tabel 1 Rekapitulasi Hasil Perhitungan Deskriptif

\begin{tabular}{|c|c|c|c|c|c|c|c|c|c|}
\hline \multicolumn{2}{|c|}{ Kelompok } & \multicolumn{7}{|c|}{ STATISTIK } & \multirow{2}{*}{} \\
\cline { 3 - 10 } \multicolumn{2}{|c|}{} & Mean & Median & Modus & Varians & $\begin{array}{c}\text { Standar } \\
\text { Deviasi }\end{array}$ & Max & Min & Jangkauan \\
\hline \multirow{2}{*}{$A_{1}$} & Pretes & 29,4 & 33,3 & 13,3 & 316,8 & 17,8 & 53,3 & 6,7 & 46,6 \\
\cline { 2 - 10 } & Postes & 78,9 & 80,0 & 80,0 & 41,5 & 6,4 & 93,3 & 66,7 & 26,6 \\
\hline \multirow{2}{*}{$A_{2}$} & Pretes & 28,3 & 30,0 & 10,0 & 294,7 & 17,2 & 53,3 & 6,7 & 46,7 \\
\cline { 2 - 10 } & Postes & 71,6 & 71,7 & 73,3 & 30,0 & 5,5 & 83,3 & 63,3 & 20,0 \\
\hline \multirow{2}{*}{$B_{1}$} & Pretes & 45,5 & 43,3 & 43,3 & 29,3 & 5,4 & 53,3 & 36,7 & 16,7 \\
\cline { 2 - 10 } & Postes & 78,4 & 80,0 & 80,0 & 55,7 & 7,5 & 93,3 & 63,3 & 30,0 \\
\hline \multirow{2}{*}{$B_{2}$} & Pretes & 12,3 & 10,0 & 10,0 & 22,2 & 4,7 & 26,7 & 6,7 & 20,0 \\
\cline { 2 - 10 } & Postes & 72,1 & 73,3 & 73,3 & 22,9 & 4,8 & 80,0 & 63,3 & 16,7 \\
\hline
\end{tabular}

Keterangan: 
$A_{1}$ : Unit observasi yang mengikuti pembelajaran dengan pendekatan pembelajaran kontekstual.

$A_{2}$ : Unit observasi yang mengikuti pembelajaran dengan pendekatan pembelajaran konvensional.

$B_{1}$ : Unit observasi yang mempunyai kemampuan numerik tinggi.

$\mathrm{B}_{2}$ : Unit observasi yang mempunyai kemampuan numerik rendah

Berdasarkan tabel 1 terlihat bahwa

terjadi peningkatan pencapaian nilai prestasi belajar matematika pada keempat kelompok.

Pengujian hipotesis dilakukan dengan menggunakan analisis kovarian (ANAKOVA) dua jalan. Adapun hasil uji ANAKOVA dua jalan tentang sumber pengaruh kovariat terhadap prestasi belajar matematika, ditemukan nilai statistik $F=19,211$ dengan sign $=0,001$. Nilai signifikansi tersebut lebih kecil dari 0,05 yang berarti kovariabel prestasi belajar matematika awal berpengaruh signifikan terhadap prestasi belajar matematika. Dengan demikian ANACOVA menjadi relevan untuk digunakan menguji hipotesis.

Hasil uji hipotesis yang diperoleh dalam penelitian ini adalah sebagai berikut. Pertama, hasil uji hipotesis pertama telah berhasil menolak $\mathrm{H}_{0}$ dan menerima $\mathrm{H}_{1}$, yang berarti bahwa terdapat perbedaan prestasi belajar matematika antara siswa yang mengikuti pendekatan pembelajaran kontekstual dengan siswa yang mengikuti pendekatan pembelajaran konvensional setelah perlakuan dikontrol dengan kovariabel prestasi belajar matematika awal. $\mathrm{Hal}$ ini dibuktikan dengan nilai statistik $F=48,458$ dengan angka signifikansi 0,001 . Oleh karena angka signifikansinya lebih kecil dari 0,05 maka variabel dependent prestasi belajar matematika secara signifikan $(p<0,05)$ dipengaruhi oleh pendekatan pembelajaran yang digunakan dalam pembelajaran. Nilai rata-rata prestasi belajar matematika siswa yang belajar dengan pendekatan pembelajaran kontekstual adalah $\mathrm{M}=78,9$ dengan $\mathrm{SD}=$ 6,4 , sedangkan nilai rata-rata prestasi belajar matematika siswa yang belajar dengan model pembelajaran konvensional adala $M=71,6$ dengan $S D=5,5$. Hal ini mengindikasikan bahwa prestasi belajar matematika siswa yang belajar dengan pendekatan pembelajaran kontekstual lebih baik daripada prestasi belajar matematika siswa yang belajar dengan pendekatan pembelajaran konvensional.

Kedua, hasil uji hipotesis kedua berhasil menolak $\mathrm{H}_{0}$ dan menerima $\mathrm{H}_{1}$, yang berarti bahwa terdapat perbedaan pestasi belajar matematika yang dicapai oleh kelompok siswa yang memiliki kemampuan numerik tinggi dengan kelompok siswa yang memiliki kemampuan numerik rendah setelah perlakuan dikontrol dengan kovariabel prestasi belajar matematika awal. Hal ini dibuktikan dengan nilai statistik $F=4,936$ dengan angka signifikansi 0,029. Oleh karena angka signifikansinya lebih kecil dari 0,05 maka variabel dependen prestasi belajar matematika secara signifikan $(p<$ $0,05)$ dipengaruhi oleh kemampuan numerik siswa. Nilai rata-rata prestasi belajar matematika siswa yang memiliki kemampuan numerik tinggi adalah $\mathrm{M}=78$ dengan $\mathrm{SD}=7,5$ sedangkan nilai rata-rata prestasi belajar matematika siswa yang memiliki kemampuan numerik rendah adaah $M=72,1$ dengan $S D=4,8$. Hal ini mengindikasikan prestasi belajar matematika siswa yang memiliki kemampuan numerik tinggi lebih tinggi daripada prestasi belajar matematika siswa yang memiliki kemampuan numerik rendah.

Ketiga, hasil uji hipotesis ketiga berhasil menolak $\mathrm{H}_{0}$ dan menerima $\mathrm{H}_{1}$ yang berarti bahwa terdapat pengaruh interkatif antar pendekatan pembelajaran (pendekatan pembelajaran kontekstual dan pendekatan pembelajaran konvensional) dengan kemampuan numerik (kemampuan numerik tinggi dan kemampuan numerik rendah) terhadap prestasi belajar matematika setelah perlakuan dikontrol dengan kovariabel prestasi belajar matematika awal. Hal ini dibuktikan dengan nilai statistik $\mathrm{F}=7,177$ dengan angka signifikansi $=0,009$. Oleh karena angka signifikansinya lebih kecil 
dari 0,05 maka dapat disimpulkan bahwa terdapat pengaruh interaktif antara pendekatan pembelajaran dan kemampuan numerik terhadap prestasi belajar matematika. Interaksi antara pendekatan pembelajaran dan kemampuan numerik dalam pencapaian prestasi belajar matematika dilukiskan pada Gambar 01. Grafik pada Gambar 1 menunjukkan bahwa kemampuan numerik siswa memberikan pengaruh yang bervariasi pada pendekatan pembelajaran yang dipergunakan.

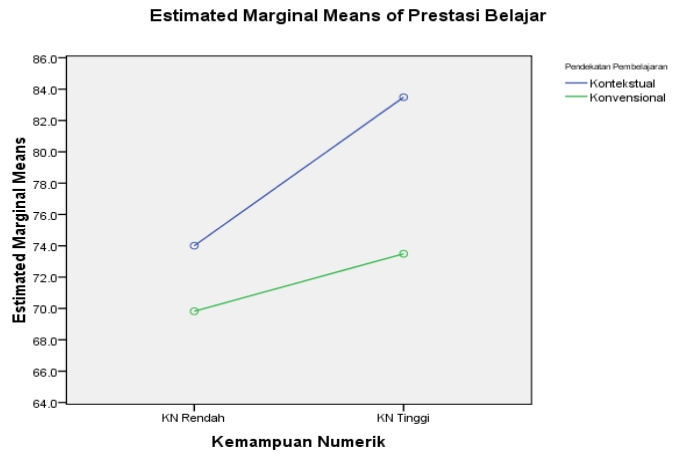

Gambar 1. Profil Interaksi Pendekatan Pembelajaran dan Kemampuan Numerik dalam Pencapaian Prestasi Belajar Matematika

Terkait dengan hasil uji pengaruh interaktif antara pendekatan pembelajaran dan kemampuan numerik terhadap prestasi belajar Matematika siswa, maka perlu dilakukan uji lanjut. Uji lanjut dilakukan dengan Post Hoc, yakni Uji Tukey HSD (Honestly Significant Difference) tes.

Hasil uji lanjut tersebut adalah sebai berikut. Pertama, secara signifikan ada perbedaan mean prestasi belajar matematika antara perlakuan pendekatan pembelajaran kontekstual kemampuan numerik tinggi dan pendekatan pembelajaran kontekstual kemampuan numerik rendah sebesar 9,47; antara pendekatan pembelajaran kontekstual kemampuan numerik tinggi dan pendekatan pembelajaran konvensional kemampuan numerik tinggi sebesar 9,99; antara pendekatan pembelajaran kontekstual kemampuan numerik tinggi dan konvensional kemampuan numerik rendah sebesar 13,66; antara pendekatan pembelajaran konvensional kemampuan numerik tinggi dan pendekatan pembelajaran konvensional keampuan numerik rendah sebesar 3,67; dan antara pendekatan pembelajaran kontekstual kemampuan numerik rendah dan pendekatan pembelajaran konvensional numerik rendah sebesar 4,18. Perbedaan tersebut ditunjukkan oleh masing-masing bilangan signifikansi yang diperoleh jauh lebih kecil daripada taraf signifikansi yang ditetapkan, yakni 0,05. Sedangkan antara pendekatan pembelajaran konvensional kemampuan numerik tinggi pendekatan pembelajaran kontekstual kemampuan numerik rendah perbedaan mean prestasi belajar matematika sebesar 0,51 dan nilai signifikansinya lebih besar dari 0,05 sehingga prestasi belajar matematika antara pendekatan pembelajaran konvensional kemampuan numerik tinggi pendekatan pembelajaran kontekstual kemampuan numerik rendah tidak berbeda secara signifikan. Kedua, skor rata-rata dari subset untuk perlakuan pendekatan pembelajaran kontekstual kemampuan numerik tinggi sebesar 83,48 ; pendekatan pembelajaran kontekstual kemampuan numerik rendah sebesar 74,00 ; pendekatan pembelajaran konvensional kemampuan numerik tinggi sebesar 73,49; dan pendekatan pembelajaran konvensional kemampuan numerik rendah sebesar 69,82. Ketiga, berdasarkan hasil uji lanjut dan besarnya skor rata-rata, maka keempat perlakuan dapat diurutkan sebagai berikut : (1) pendekatan pembelajara kontekstual kemampuan numerik tinggi, (2) pendekatan pembelajaran kemampuan numerik rendah dan pendekatan pembelajaran konvensional kemampuan numerik tinggi dan (3) pendekatan pembelajaran konvensional kemampuan numerik rendah. Dengan demikian dapat diinterpretasikan bahwa interaksi antara pendeatan pembelajaran kontekstual dengan kemampuan numerik tinggi memberikan pengaruh yang paling baik terhadap prestasi belajar matematika. Selanjutnya yang kedua adalah interaksi 
pendekatan pembelajaran kontekstual dengan kemampuan numerik rendah dan interaksi antara pendekatan pembelajaran konvensional dengan kemampuan numerik tinggi dan yang terakhir adalah interaksi antara pendekatan pembelajaran konvensional dengan kemampuan numerik rendah.

\section{PENUTUP}

Berdasarkan hasil penelitian dan pembahasan, maka dapat diuraikan menjadi tiga simpulan hasil penelitian, yang merupakan jawaban terhadap tiga masalah yang diajukan dalam penelitian ini. Ketiga simpulan tersebut adalah sebagai berikut.

Pertama, Setelah perlakuan dikontrol dengan kovariabel prestasi belajar matematika awal, terdapat perbedaan prestasi belajar matematika antara siswa yang mengikuti pendekatan pembelajaran kontekstual dan siswa yang mengikuti pendekatan pembelajaran konvensional. Prestasi belajar matematika siswa yang mengikuti pendekatan pembelajaran kontekstual lebih tinggi dibandingkan dengan kelompok siswa yang mengikuti pendekatan pembelajaran konvensional. Nilai rata-rata prestasi belajar matematika siswa yang belajar dengan pendekatan pembelajaran kontekstual lebih tinggi dari pada nilai rata-rata prestasi belajar Matematika siswa yang belajar dengan pendekatan pembelajaran konvensional, hal ini mengindikasikan bahwa pendekatan pembelajaran kontekstual lebih baik dibandingkan dengan pendekatan pembelajaran konvensional dalam pencapaian prestasi belajar matematika siswa

Kedua, setelah perlakuan dikontrol dengan kovariabel prestasi belajar matematika awal, terdapat perbedaan prestasi belajar matematika antara siswa yang memiliki kemampuan numerik tinggi dan siswa yang memiliki kemampuan numerik rendah. Prestasi belajar matematika siswa yang memiliki kemampuan numerik tinggi lebih tinggi dibandingkan dengan prestasi belajar matematika siswa yang memiliki kemampuan numerik rendah.
Ketiga, setelah perlakuan dikontrol dengan kovariabel prestasi belajar matematika awal, terdapat pengaruh interaktif antara pendekatan pembelajaran dengan kemampuan numerik siswa terhadap prestasi belajar matematika siswa. Secara signifikan ada perbedaan mean prestasi belajar matematika antara perlakuan pendekatan pembelajaran kontekstual kemampuan numerik tinggi dan pendekatan pembelajaran kontekstual kemampuan numerik rendah, antara pendekatan pembelajaran kontekstual kemampuan numerik tinggi dan pendekatan pembelajaran konvensional kemampuan numerik tinggi, antara pendekatan pembelajaran kontekstual kemampuan numerik tinggi dan konvensional kemampuan numerik rendah, antara pendekatan pembelajaran konvensional kemampuan numerik tinggi dan pendekatan pembelajaran konvensional keampuan numerik rendah, dan antara pendekatan pembelajaran kontekstual kemampuan numerik rendah dan pendekatan pembelajaran konvensional numerik Sedangkan antara pendekatan pembelajaran konvensional kemampuan numerik tinggi dan pendekatan pembelajaran kontekstual kemampuan numerik rendah tidak berbeda secara signifikan. Interaksi antara pendekatan pembelajaran kontekstual kemampuan numerik tinggi merupakan kombinasi yang paling baik untuk meningkatkan prestasi belajar matematika siswa,kemudian diikuti oleh interaksi antara pendekatan pembelajaran kemampuan numerik rendah dan pendekatan pembelajaran konvensional kemampuan numerik tinggi dan serta pendekatan pembelajaran konvensional kemampuan numerik rendah.

Sehubungan dengan hal tersebut beberapa saran yang dapat disampaikan dari hasil penelitian ini antara lain sebagai berikut.

Pertama, diharapkan guru mampu menerapkan pendekatan pembelajaran secara tepat, dari segi materi pelajaran dan juga kondisi siswa agar pembelajaran matematika lebih kreatif, inovatif, menyenangkan, dan bermanfaat nyata, 
salah satunya adalah menerapkan pendekatan pembelajaran kontekstual. Pendekatan pembelajaran kontekstual terbukti mampu meningkatkan prestasi belajar siswa Kedua, diharapkan kepada para guru untuk menyusun bahan ajar sebagai pendukung model pembelajaran realistik setting kooperatif.

Kedua, Untuk siswa agar terus meningkatkan kemampuan numeriknya dengan melakukan latihan lebih efktif sehingga dengan semakin meningkatnya kemapuan numerik siswa akan berimplikasi pada meningkatnya prestasi belajar siswa.

Ketiga, Kepada para peneliti lain yang berminat untuk melakukan penelitian lebih lanjut, disarankan untuk melakukan penelitian yang melibatkan variabel bebas yang berfungsi sebagai moderator lainnya misalnya kemampuan verbal siswa.

\section{DAFTAR RUJUKAN}

Arikunto, S. 2006. Prosedur penelitian suatu pendekatan praktik. Jakarta: PT Rineka Cipta.

Atmaja, P. G., Lasmawan, I W., \& Natajaya, N. 2014. Pengaruh pendekatan pembelajaran kontekstual terhadap sikap sosial dan hasil belajar dalam pembelajaran IPS kelas $\mathrm{V}$ di SD negeri gugus Singakerta kecamatan Ubud kabupaten Gianyar. e-Journal Program Pascasarjana Universitas Pendidikan Ganesha. 4: 1-10. Tersedia pada http://pasca.undiksha.ac.id /ejournal/index.php/jurnal_pendas/ article/viewFile/1116/862. Diakses 24 Maret 2016.

Budimah, Herpratiwi, \& Rosidin, U. 2014. Pengembangan modul pembelajaran IPA berbasis karakter materi kalor SMP kelas VII di Bandar Lampung. Jurnal Sains dan Pendidikan. 1(1): 1-8. Tersedia pada http://pasca.unila.ac .id/wpcontent/uploads/2015/11/3.

Diakses 23 Februari 2016.
BSNP. 2006. Permendiknas no.22 tahun 2006 tentang standar isi untuk satuan pendidikan dasar dan menengah. Jakarta: Depdiknas.

Candiasa. 2011. Statistik multivariat disertai aplikasi SPSS. Singaraja: Undiksha Press.

Dandy. 2010. Tes Bakat atau Aptitude Test. Tersedia pada http: //dandy. student. fkip. uns. ac. id/2010/06/28/tes-bakat-atauaptitude-test/. Diakses 19 Oktober 2016

Departemen Pendidikan Nasional. 2002. Pendekatan kontekstual (contextual teaching and learning). Jakarta: Depdiknas.

Dimyati \& Mudjiono. 2002. Belajar dan pembelajaran. Jakarta: PT. Rineka Cipta.

Ekowati, C. K., Darwis, M., Upa, H. M. D. P., \& Tahmir, S. 2015. The application of contextual approach in learning mathematics to improve students motivation at SMPN 1 Kupang. International Education Studies. 8(8): 81-86. Tersedia pada http://dx.doi.org/10.5539/

ies.v8n8p81. Diakses 4 Maret 2016.

Fraenkel, J.R. \& Wallen, N.E. (2008). How to design and evaluate research in education. Second edition. New york: Mcgrow-Hill Book Com

Hadjar, I. 1999. Dasar-dasar metodologi penelitian kwalitatif dalam pendidikan. Jakarta: Raja Grafindo Persada

Isworo, D., Sunarno, W., \& Wahyuningsih, D. 2014. Hubungan antara kreativitas siswa dan kemampuan numerik dengan kemampuan kognitif fisika siswa SMP kelas VIII. Jurnal Pendidikan Fisika. 2(2): 3538. Tersedia pada 
http://jurnal.fkip.uns.ac.id/ index.php/ pfisika/article/view/4675. Diakses 22 Maret 2016.

Johnson, E. B. 2002. Contextual teaching and learning: what it is and why it's here to stay. United States of America: Corwin press, Inc.

Jihad, A. \& Haris, A. 2009. Evaluasi pembelajaran. Yogyakarta: Multi Press.

Majid, A. 2009. Perencanaan pembelajaran mengembangkan standar kompetensi guru. Bandung: PT Remaja Rosdakarya.

Marsi, N. N. 2014. Pengaruh model pembelajaran kooperatif tipe STAD dan kemampuan Abstraksi terhadap prestasi belajar matematika siswa. Tesis (Tidak diterbitkan). Program Studi teknologi Pembelajaran, Program Pascasarjana, Undiksha Singajara.

Munandar, S. C. U. 1992. Mengembangkan bakat dan kreatifitas anak sekolahan. Jakarta: Gramedia Widiasarana.

Nartani, C. I., Hidayat, R. A., \& Sumiyati, Y. 2015. Communicaton in Mathematics Contextual. International Journal of Innovation and Research in Educational Sciences. 2(4): 1-4. Tersedia pada http://

www.ijires.org/administrator/compo nents/com jresearch/files/publicati ons/IJIRES_314_Final.pdf. Diakses 15 Maret 2016

Nasrun. 2014. Contextual learning approach in improving critical thinking skills of guidance and counseling students of state university of Medan. International Journal of Sciences: Basic and Applied Research. 18(1): 151-161. Tesedia pada http://gssrr.org/ index.php?journal=JournalOf
BasicAndApplied. Diakses 4 Maret 2016.

Nasution. 2001. Hubungan metode mengajar dosen, keterampilan mengajar, sarana belajar, dan lingkungan belajar dengan prestasi belajar mahasiswa. Jurnal IImu Pendidikan. 8(1). Tersedia pada http://isjd.pdii.lipi.go.id/ index.php/ Search.html?act=tampil\&id=34348 \&idc=32. Diakses 16 Maret 2016.

Nuridawani, Munzir, S., \& Saiman. 2015. Peningkatan kemampuan penalaran matematis dan kemandirian belajar siswa Madrasah Tsanawiyah (MTs) melalui pendekatan contextual teaching and learning (CTL). Jurnal Didaktik Matematika. 2(2): 1-13. Tersedia pada http://www.jurnal.unsyiah .ac.id/DM/article/view/2815. Diakses 11 Maret 2016.

Nurkencana. 2005. Evaluasi hasil belajar mengajar. Surabaya: Usaha Nasional.

Rusman, 2010. Model-model pembelajaran mengembangkan profesionalisme guru. Jakarta: PT. RajaGrafindo Persada.

Rosalin, E. 2008. Gagasan merancang pembelajaran kontekstual. Bandung: PT Karsa Mandiri Persada.

Sanjaya, W. 2006. Strategi pembelajaran. Jakarta: Kencana Prenada Media Group.

Santyasa, I W. 2012. Pembelajaran inovatif. Singaraja: Universitas Pendidikan Ganesha.

Santyasa, I W. 2014. Assesmen dan evaluasi pembelajaran fisika. Yogyakarta: Graha IImu. 
Slameto. 2003. Belajar dan faktor-faktor yang mempengaruhinya. Jakarta: Rineka Cipta

Slavin, R. E. 2011. Psikologi pendidikan: Teori dan praktik. Edisi kesembilan jilid 1. Jakarta: PT Indeks.

Suarniti, A. A. S., Dantes, N., \& Widiartini, K. 2015. Pengaruh implementasi pendekatan pembelajaran kontekstual terhadap prestasi belajar matematika dengan kovariabel kemampuan numerik pada siswa kelas VI SDN di gugus Sukawati 1. e-Journal Program Pascasarjana Universitas Pendidikan Ganesha. 5(1): 1-11. Tersedia pada http:// pasca.undiksha.ac.id/ejournal/index.php/jurnalep/article/vi ew/1576. Diakses 23 Februari 2016.

Sugiyono. 2011. Statistika untuk penelitian. Bandung: Alfabeta.

Sumarjono, S. 2009. Psikotes lengkap terkini. Jogakarta.: Diva Press.

Trianto. 2008. Mendesain pembelajaran kontekstual (contextual teaching and learning) di Kelas. Jakarta: Cerdas Pustaka Publiser.

Trianto. 2009. Mendesain model pembelajaran inovatif-progresif.
Jakarta: Kencana Kharisma Media Group.

Umriyah. 2011. Pengaruh penerapan pendekatan kontekstual berbasis asesmen kinerja terhadap hasil belajar matematika ditinjau dari kebiasaan belajar siswa Madrasah Tsanawiyah (studi sksperimen pada MTs Miftahul'Ulum Denpasar). Tesis (tidak diterbitkan). Program Studi Penelitian dan Evaluasi Pendidikan, Program Pascasarjana, Universitas Pendidikan Ganesha.

Warpala, I W. S. 2006. Pengaruh pendekatan pembelajaran dan strategi belajar kooperatif yang berbeda terhadap pemahaman dan keterampilan berpikir kritis dalam pembelajaran IPA SD. Disertasi (tidak diterbitkan). Program Studi Teknologi Pembelajaran, Program Pascasarjana, Universitas Negeri Malang.

Wiswayana, N. P. 2007. Pengaruh pembelajaran berbasis masalah dan adversity quotient siswa terhadap prestasi belajar matematika dan konsep diri siswa SMA Negeri 4 Singaraja. Tesis. (Tidak diterbitkan). Program Pascasarjana, Undiksha Singaraja. 